\title{
Physical fitness and anthropometric normative values among Colombian-Indian schoolchildren
}

\author{
Jeison Alexander Ramos-Sepúlveda ${ }^{1,2}$, Robinson Ramírez-Vélez ${ }^{3 *}$, Jorge Enrique Correa-Bautista ${ }^{3}$, \\ Mikel Izquierdo ${ }^{4}$ and Antonio García-Hermoso ${ }^{5,6}$
}

\begin{abstract}
Background: Substantial evidence indicates that children's physical fitness levels are markers of their lifestyles and their cardio-metabolic health profile and are predictors of the future risk of chronic diseases such as obesity, cardiometabolic disease, skeletal health and mental health. However, fitness reference values for ethnic children and adolescents have not been published in a Latin-American population. Therefore, the aim of the study was to provide sex-and age-specific physical fitness and anthropometric reference standards among Colombian-Indian schoolchildren.

Methods: A sample of 576 participants (319 boys and 257 girls) aged 10 to 17 years old was assessed using the FUPRECOL test battery. Four components of physical fitness were measured: 1) morphological component: height, weight, body mass index (BMI), waist circumference (WC), triceps skinfold, subscapular skinfold, and body fat (\%); 2) musculoskeletal component: handgrip and standing long jump test; 3) motor component: speed/agility test (4×10 m shuttle run); and 4) cardiorespiratory component: course-navette $20 \mathrm{~m}$, shuttle run test and estimation of maximal oxygen consumption by $\mathrm{VO}_{2}$ max indirect. Centile smoothed curves for the $3^{\text {td }}, 10^{\text {th }}, 25^{\text {th }}, 50^{\text {th }}, 75^{\text {th }}, 90^{\text {th }}$ and $97^{\text {th }}$ percentiles were calculated using Cole's LMS method.
\end{abstract}

Results: Our results show that weight, height and BMI in each age group were higher in boys than in girls. In each groups, age showed a significant effect for BMI and WC. Boys showed better than girls in cardiorespiratory fitness, lowerand upper-limb strength and speed/agility and girls performed better in low back flexibility.

Conclusion: Our results provide for the first time sex- and age-specific physical fitness and anthropometric reference values for Colombian Nasa Indian children and adolescents aged 10-17.9 years.

Keywords: Physical fitness, Body composition, Obesity, Adolescent, Reference standards

\section{Background}

Physical fitness is a multi-dimensional construct that includes skills and health related components, of which cardiorespiratory fitness (CRF) and muscular fitness in particular are powerful determinants of health in youth [1]. Substantial evidence indicates that children's physical fitness levels are markers of their lifestyles and their cardio-metabolic health profile and are predictors of the future risk of chronic diseases [2-6], such for obesity,

\footnotetext{
* Correspondence: robin640@hotmail.com; robinson.ramirez@urosario.edu.co ${ }^{3}$ Centro de Estudios en Medición de la Actividad Física (CEMA), Escuela de Medicina y Ciencias de la Salud, Universidad del Rosario, Bogotá, D.C, Colombia

Full list of author information is available at the end of the article
}

cardiovascular disease, skeletal health and mental health [1]. Physical fitness is also inversely associated with metabolic risk $[7,8]$ and is a valuable part of health monitoring in children $[1,8]$ and adults [9].

The inclusion of physical fitness within health surveillance systems is therefore clearly justifiable, and schools may be an ideal setting for the monitoring of youth fitness. Various health-related fitness test batteries are used to assess young people internationally, including the FUPRECOL battery [9], FITNESSGRAM battery [10], the President's Challenge: Health Fitness [11], the EUROFIT [12], the CPAFLA [13], and the AFEA battery [14]. Recently, the Assessing Levels of Physical Activity (ALPHA) health-related fitness test battery was created as part of 
the framework of the EU- funded project, the HELENA Study "Healthy Lifestyle in Europe by Nutrition in Adolescence", to be used in public health monitoring in a comparable way within the European Union [15]. The fitness tests included in the FUPRECOL health-related fitness battery assess the main components of fitness that have a relationship with health such as (a) morphological and body composition, (b) musculoskeletal fitness, (c) motor fitness, and (d) cardiorespiratory fitness.

However, race and ethnicity are also thought to be important determinants of health [16]. Both are terms used to categorize populations on the basis of shared characteristics. Race has traditionally been used to categorize populations on the basis of shared biological characteristics such as genes, skin color, and other observable features [17]. Ethnicity is used to categorize on the basis of cultural characteristics such as shared language, ancestry, religious traditions, dietary preferences, and history. Although ethnic groups can share a range of phenotypic characteristics because of their shared ancestry, the term is typically used to highlight cultural and social characteristics instead of biological ones $[8,11]$.

Indigenous populations have disparities in health along with disparities in modifiable risk factors, including a low participation in physical activity [8]. For instance, inequalities in nutrition may be related to race/ethnicity inequalities and household characteristics [18]. Although the relationship between race/ethnicity and obesity in children is inconsistent in developed countries, there appears to be a strong positive association between the two in developing countries [19]. The obesity-race/ethnicity association could vary by sex, age, and country [20]. Middle-income countries such as Colombia are experiencing rapid urbanization and integration into global markets, which leads to changes in diet and physical activity and, with these changes, large effects on body composition $[9,19]$. These changes in body composition are contributing to a global increase in the prevalence of noncommunicable diseases. Data on the physical fitness of Indigenous youth are scarce; therefore the inclusion of fitness within health surveillance systems is clearly justifiable and may be an ideal setting for the monitoring of youth fitness in indigenous population. It is important to document the current state of physical fitness in Colombia, particularly among the most vulnerable groups including low income, rural populations, indigenous households, women and children.

Therefore, the aim of the study was to provide sex-and age-specific physical fitness and anthropometric reference standards among Colombian-Indian schoolchildren.

\section{Methods}

\section{Participants and study design}

Indigenous populations have disparities in health along with disparities in modifiable risk factors, including low participation in physical activity [8]. The present crosssectional study was conducted to provide the distribution of health-related physical fitness across indigenous individuals. Data were collected in the Nasa community, located in the Toribío district, which is a town and municipality in Cauca Department, South Colombia. Nasa is considered an indigenous area, with approximately $90 \%$ of the 186,178 inhabitants living in the surrounding rural areas. Data from the National Institute of Statistics in Colombia) indicate that the estimated prevalence of poverty is substantially higher in the Nasa indigenous (93\%) [21].

\section{Subjects}

A sample of 576 (319 boys and 257 girls) healthy, Nasa Indian children and adolescents (10-17.9 years old) participated in the study. All the participants of the selected indigenous households were invited to participate in the study. The participation rate was greater than $95 \%$. A convenience sample of volunteers was included in groups by sex and age with 1-year increments (a total of 8 groups). The sample size was estimated at 15 to 30 participants per group. A power analysis showed that this sample size was sufficient to estimate the proportion of subjects with an aerobic capacity indicative of future cardiovascular risk (7 to $11 \%$ ) with a precision of $11.4 \%$ and a power of $80 \%$ by data from the FUPRECOL study [9]. The recruitment period lasted from June 2014 to January 2015.

\section{Ethics approval and consent to participate}

A comprehensive verbal description of the nature and purpose of the study and of the experimental risks was given to the participants and their parents/guardians. Parents/ guardians were informed about the study via the school administration and could opt out if they disagreed with their schoolchildren participation. Participation in the study was fully voluntary and anonymous, with no explicit incentives provided for participation. Participants and their legal representatives received information sheets and all provided written informed consent and approval to take part in the study. The study was approved by the Review Committee for Research Human Subjects at the University of Manuela Beltrán (Resolution UMB No 02-1902-2014). The protocol was in accordance with the latest revision of the Declaration of Helsinki.

\section{Procedures}

\section{Morphological component}

Weight was measured to the nearest $0.1 \mathrm{~kg}$. Height was measured to the nearest $0.1 \mathrm{~cm}$. Waist circumference (WC) was measured by horizontally placing an inelastic tape measure midway between the lowest rib margin and the iliac crest to the nearest $0.1 \mathrm{~cm}$. The instruments were calibrated to ensure acceptable accuracy. 
Body mass index (BMI) was calculated as body weight in kilograms divided by height squared in meters. The participants were categorized according to the BMI international cut-off values as normal weight, overweight, and obese [22]. During the anthropometric measurements, the students wore light clothing and were barefoot. Skinfold thicknesses (triceps and subscapular) were measured at the left side of the body to the nearest $0.1 \mathrm{~mm}$ using a Holtain skinfold caliper. The triceps thickness was measured at halfway between the acromion process and the olecranon process; subscapular thickness was measured approximately $20 \mathrm{~mm}$ below the tip of the scapula, at an angle of $45^{\circ}$ to the lateral side of the body. Body fat (\%) was also calculated using the formulas described by Slaughter et al. [23]. The predicted \% body fat cut-off values for obesity used in this work by age and sex was $25-30 \%$ in boys and $30-53 \%$ in girls [24].

\section{Musculoskeletal component}

Explosive strength, standing broad jump (cm) The participants stood behind the starting line and were instructed to push off vigorously and jump as far as possible. The participants had to land with their feet together and remain upright. The test was repeated twice, and the best score was retained. The farther of the two scores was recorded to the nearest $0.1 \mathrm{~cm}$ as the distance between toes at take-off and heels at landing, or whichever body part landed nearest to the take-off.

Handgrip strength (kg) Handgrip strength was measured using a standard adjustable handle analogue handgrip dynamometer T-18 TKK SMEDLY III ${ }^{\bullet}$ (Takei Scientific Instruments Co., Ltd, Niigata, Japan). Handgrip strength was measured with the subject in a standing position with their shoulders adducted and neutrally rotated and their arms parallel but not in contact with the body. The participants were asked to squeeze the handle maximally for 3-5 s, but no verbal encouragement was given during the test. Two trials were performed on each side, alternately, with a rest period of at least $1 \mathrm{~min}$ between trials of the same hand. Thus, the reference values of handgrip strength presented here combine the results of left and right-handed subjects, without consideration of hand dominance.

Motor component: speed/agility test (speed of movement, agility and coordination assessment) Two parallel lines were drawn on the floor $10 \mathrm{~m}$ apart. The adolescents ran as fast as possible from the starting line to the other line and returned to the starting line, crossing each line with both feet every time. This was performed twice, covering a distance of $40 \mathrm{~m}(4 \times 10 \mathrm{~m})$. Every time the adolescents crossed any of the lines, he/ she would pick up (the first time) or exchange (second and third times) a sponge that had earlier been placed behind the lines. The stopwatch was stopped when the adolescents crossed the end line with one foot. The time taken to complete the test was recorded to the nearest tenth of a second. A slip-proof floor, four cones, a stopwatch and three sponges were used to perform the test.

\section{Cardiorespiratory component}

Cardiorespiratory fitness, 20-m shuttle run $\left(\mathbf{m l} \bullet \mathbf{k g} \bullet \mathbf{m i n}^{-\mathbf{1}}\right)$ The participants ran in a straight line between two lines $20 \mathrm{~m}$ apart, while keeping pace with pre-recorded audio signals. The initial speed was $8.5 \mathrm{~km} / \mathrm{h}$ and increased by $0.5 \mathrm{~km} / \mathrm{h}$ per minute. The test was finished when the participant failed to reach the end lines keeping pace with the audio signals on two consecutive occasions or when the subject stopped because of fatigue. The results were recorded to the nearest stage (minute) completed. To estimate $\mathrm{VO}_{2} \max$ using the 20-m shuttle run, the equation developed by Leger et al. [25] was used: $\left[\mathrm{VO}_{2 \max }=31.025+3.238\right.$ "V3.248 *A + 0.1536 "V *A]. Here, "V" accounts for velocity (in $\mathrm{km} / \mathrm{h}^{-1}$ ) of the last completed stage and " $\mathrm{A}$ " accounts for the subject's age (in years) $[25,26]$.

\section{Sexual maturation}

Sexual maturation was classified on the basis of Tanner staging (self-reported pubertal status) as: prepubescent, pubescent, and postpubescent [27]. Each volunteer entered an isolated room, where, using a set of images exemplifying the various stages of sexual maturation, they categorized the development of their own genitalia (for boys), breasts (for girls), armpits (for boys) and pubic hair (for both genders). The reproducibility of our data reached $85 \%$. With regard to the communication processes and explanations of tests, direct and simple oral language was used. Additionally, the evaluators provided visual models and examples before performing the test, when necessary. The participants did not receive specific training on these tests previously.

All fit measurements in a subsample of $(n=124)$ boys and $(n=105)$ girls [mean weight $=46.2 \pm 12.4 \mathrm{~kg}$, mean height $=1.50 \pm 0.1 \mathrm{~m}$, mean $\mathrm{BMI}=19.9 \pm 3.1$, mean age $=12.8 \pm 2.4$ years] were repeated by undergoing the tests again 1 week later. The same inter-trial period has been used earlier in similar reliability studies conducted with healthy young individuals [28]. In all the tests, we found almost excellent test-retest reliability [waist circumference (ICC $=0.983$ ), BMI (ICC = $0.973)$, triceps skinfold $(\mathrm{ICC}=0.864)$, subscapular skinfold $(\mathrm{ICC}=0.859)$, handgrip $(\mathrm{ICC}=0.984)$, standing long jump test $(\mathrm{ICC}=0.921)$, set and reach $(\mathrm{ICC}=$ $0.899)$, and course-navette shuttle run test $(\mathrm{ICC}=$ $0.967)$ ], with the exception of the $4 \times 10 \mathrm{~m}$ shuttle run, which obtained a moderate agreement $($ ICC $=0.685)$. 


\section{Statistical analyses}

All variables were checked for normality of distribution before analysis using histograms and Q-Q plots. None required transformation. The participants were divided into 8 age groups: 10 to $10.9,11$ to $11.9,12$ to $12.9,13$ to $13.9,14$ to $14.9,15$ to $15.9,16$ to 16.9 and 17 to 17.9 years. The ageand sex-specific values were reported as the mean \pm the standard deviation (SD). We analyzed sex-group differences in the fitness variables by a one-way analysis of variance. To provide percentile values for the sample, we analyzed waist circumference, BMI, triceps skinfold, subscapular skinfold, handgrip, standing long jump test, $4 \times 10 \mathrm{~m}$ shuttle run and course-navette shuttle run test data by maximum penalized likelihood using the LMS statistical method for boys and girls separately [29]. We derived smoothed centile charts using the LMS method. This estimates the measurement percentiles in terms of three agespecific cubic spline curves: the L curve (Box-Cox power to remove skewness), the $\mathrm{M}$ curve (median) and the $\mathrm{S}$ curve (coefficient of variation). The appropriate number of degrees of freedom was selected on the basis of the deviance, Q-tests and worm plots, following the suggestions of Royston \& Wright [30]. The $3^{\text {rd }}, 10^{\text {th }}, 25^{\text {th }}, 50^{\text {th }}, 75^{\text {th }}, 90^{\text {th }}$ and $97^{\text {th }}$ smoothing percentiles were chosen as the ageand gender-specific reference values. For the construction of the percentile curves, the data were imported into the LmsChartMaker software (V. 2.3; by Tim Cole and Huiqi Pan), and the L, M and S curves were estimated [31]. Except for the LMS method calculations, we used SPSS V. 21 software for Windows (SPSS, Chicago, IL, USA), and the significance level was set at $5 \%$.

\section{Results}

\section{Descriptive characteristics}

The characteristics for the four components of the FUPRECOL health-related fitness test according to the sex and age of the study sample are shown in Table 1. The mean values were as follows: age of $14.3 \pm 2.2$ years, weight of $46.1 \pm 10.6 \mathrm{~kg}$, height of $148.2 \pm 11.6 \mathrm{~m}$, BMI of $20.7 \pm 2.7 \mathrm{~kg} / \mathrm{m}^{2}$, waist circumference of $70.0 \pm$ $7.3 \mathrm{~cm}$, subscapular skinfold of $10.3 \pm 3.7 \mathrm{~mm}$, triceps skinfold of $12.5 \pm 6.1 \mathrm{~mm}$ and body fat of $21.8 \pm 5.5 \%$. The prevalence of overweight and obesity were significantly higher in girls $(p=0.001)$. Girls had a significantly higher \% body fat and a significantly higher WC ( $p=$ 0.001). Handgrip strength, standing broad jump and $\mathrm{VO}_{2} \mathrm{max}$ were significantly different between sexes, and boys had significantly higher scores in the musculoskeletal component $(p=0.001)$, the cardiorespiratory component $(p=0.001)$ and the motor component $(p=0.001)$.

\section{Normative values}

Tables 2 and 3 show the normative values for waist circumference, BMI, triceps skinfold, subscapular skinfold, handgrip strength, standing long jump test, $4 \times 10 \mathrm{~m}$ shuttle run and the course-navette shuttle run test in the Nasa Indian Community, classified according to sex and age and expressed in percentiles from 3 to 97. In boys, the BMI and WC $50^{\text {th }}$ percentiles ranged from 16.8 to $23.5 \mathrm{~kg} / \mathrm{m}^{2}$ and 62.3 to $74.2 \mathrm{~cm}$, respectively. In girls, the BMI and WC $50^{\text {th }}$ percentiles ranged from 16.1 to $20.1 \mathrm{~kg} / \mathrm{m}^{2}$ and 64.0 to $76.5 \mathrm{~cm}$, respectively (Fig. 1). Skinfolds in each age group were significantly higher in girls than in boys (Fig. 1). Boys performed better than girls in terms of the musculoskeletal component (handgrip strength, explosive lower body strength, and standing broad jump values) (Fig. 2). The mean $4 \times 10 \mathrm{~m}$ shuttle-run values show a decreasing trend with age and sex, as shown in Table 3 . The $\mathrm{VO}_{2}$ max $50^{\text {th }}$ percentile (10 and 17 years) ranged from 51.2 to $52.8 \mathrm{ml} \cdot \mathrm{kg} \cdot \mathrm{min}^{-1}$ in boys and from 37.2 to $49.1 \mathrm{ml} \bullet \mathrm{kg} \bullet \mathrm{min}^{-1}$ in girls. Nevertheless, values show a decreasing trend with age in girls (Fig. 2).

Finally, comparisons between the $50^{\text {th }}$ percentile or mean values for physical fitness outcomes from our study and other international studies are presented in Table 4. We found that Colombian-Indian schoolchildren have higher values of CRF, standing broad jump and $4 \times 10 \mathrm{~m}$ run except in handgrip test than children and adolescents from Colombia, UK and the European Union (EU).

\section{Discussion}

The main objectives of this study were to provide sex- and age-specific physical fitness and anthropometric reference standards among Colombian-Indian schoolchildren. These results showed that the boys performed better than the girls in speed, lower- and upper-limb strength and cardiorespiratory fitness. However, this is the first published research study using the FUPRECOL test battery [9] in a sample of Colombian indigenous youths. The main strength of this study, and in terms of the normative values hereby provided, is the strict standardization of the fieldwork among the Indian community.

\section{Normative values}

Anthropometric indicators are useful both at an individual and population level. At an individual level, anthropometric body indicators can be used to assess compromised health or nutrition wellbeing. At the population level, body composition can be used to assess the nutrition status within a country, region, community, or socioeconomic group, and to study both the determinants and consequences of malnutrition and/or other risk factors [32]. This form of monitoring is valuable both for the design and targeting of health and nutrition interventions, particularly among minority populations [33].

This study shows a prevalence of overweight, including obesity, of $14.3 \%$ in boys and $25.3 \%$ in girls according 
Table 1 Means and SD for Physical Fitness and Anthropometric Normative Values among Colombian-Indian Schoolchildren

\begin{tabular}{|c|c|c|c|c|}
\hline & Total $(n=576)$ & Boys $(n=319)$ & Girls $(n=257)$ & $p$ value \\
\hline \multicolumn{5}{|l|}{ Morphologic component } \\
\hline Age (years) & $14.3 \pm 2.2$ & $14.4 \pm 2.2$ & $14.1 \pm 2.2$ & 0.198 \\
\hline Weight (kg) & $46.1 \pm 10.6$ & $46.3 \pm 11.3$ & $45.8 \pm 9.7$ & 0.634 \\
\hline Height (m) & $148.2 \pm 11.6$ & $150.4 \pm 13.1$ & $145.4 \pm 8.8$ & 0.000 \\
\hline Body mass index $\left(\mathrm{kg} / \mathrm{m}^{2}\right)$ & $20.7 \pm 2.7$ & $20.1 \pm 2.2$ & $21.5 \pm 3.1$ & 0.001 \\
\hline \multicolumn{5}{|l|}{ Weight status $n(\%)$} \\
\hline Normal weight & $494(85.8)$ & $192(74.7)$ & $302(94.7)$ & 0.001 \\
\hline Overweight & $77(13.4)$ & $62(24.1)$ & $15(4.7)$ & 0.001 \\
\hline Obese & $5(0.9)$ & $3(1.2)$ & $2(0.6)$ & 0.001 \\
\hline Waist circumference $(\mathrm{cm})$ & $70.0 \pm 7.3$ & $69.1 \pm 6.6$ & $71.1 \pm 8.0$ & 0.001 \\
\hline Subscapular skinfold (mm) & $10.3 \pm 3.7$ & $8.3 \pm 2.6$ & $12.8 \pm 3.3$ & 0.001 \\
\hline Triceps skinfold (mm) & $12.5 \pm 6.1$ & $9.2 \pm 3.2$ & $16.6 \pm 6.5$ & 0.001 \\
\hline Body fat (\%) & $21.8 \pm 5.5$ & $19.8 \pm 4.5$ & $24.2 \pm 5.7$ & 0.001 \\
\hline Adiposity excess $n(\%)$ & $113(19.6)$ & $33(12.8)$ & $90(28.2)$ & 0.001 \\
\hline \multicolumn{5}{|l|}{ Tanner stage $n(\%)$} \\
\hline Prepubescent & $176(30.6)$ & $92(35.7)$ & $106(33.2)$ & 0.309 \\
\hline Pubescent & 199 (34.6) & $88(34.3)$ & $110(34.5)$ & 0.458 \\
\hline Postpubescent & $200(34.8)$ & 77 (30.0) & $107(33.4)$ & 0.674 \\
\hline \multicolumn{5}{|l|}{ Musculoskeletal component } \\
\hline Handgrip (kg) & $20.4 \pm 7.7$ & $23.2 \pm 8.4$ & $17.0 \pm 4.8$ & 0.001 \\
\hline Standing broad jump (cm) & $151.6 \pm 31.7$ & $169.9 \pm 28.3$ & $128.9 \pm 18.0$ & 0.001 \\
\hline \multicolumn{5}{|l|}{ Motor component } \\
\hline $4 \times 10 \mathrm{~m}$ shuttle run $(\mathrm{s})$ & $11.9 \pm 1.2$ & $11.3 \pm 0.9$ & $12.7 \pm 1.0$ & 0.001 \\
\hline \multicolumn{5}{|l|}{ Cardiorespiratory component } \\
\hline 20-m shuttle run (stage) & $7.2 \pm 2.5$ & $8.6 \pm 2.2$ & $5.5 \pm 1.8$ & 0.001 \\
\hline $\mathrm{VO}_{2} \max \left(\mathrm{ml} \cdot \mathrm{kg} \cdot \mathrm{min}^{-1}\right)$ & $47.7 \pm 6.7$ & $51.5 \pm 4.7$ & $43.1 \pm 5.9$ & 0.001 \\
\hline
\end{tabular}

Mean \pm standard deviation, except weight status and adiposity excess (\%). Differences between boys and girls calculated using one-way analysis of variance and weight status future cardiovascular risk ( $\mathrm{X}^{2}$ test)

to BMI. The present results clearly show greater and more homogenous anthropometry body composition data in girls, except for BMI, in which the values in boys were slightly higher. Therefore, BMI cutoffs appear to be a good criterion for the screening of excess body fat in adolescents; however, an important percentage of subjects classified as overweight or obese did not really have excess adiposity [34].

In Colombia, the major part of the indigenous community living in high-poverty areas has been associated with a higher prevalence of overweight/obesity and hypertension, even after controlling for physical activity, BMI, and occupation [35]. Nevertheless, guidelines exist to identify, evaluate, and treat overweight/obese children [36], but there is insufficient evidence to recommend a specific treatment approach according to the race/ethnicity of the child. Although the implication of a given BMI is known to differ by race and ethnicity in adults, analogous data are lacking in children [17].
Expert panels have recommended measuring triceps and subscapular skinfold thicknesses as part of the indepth medical assessment of children and adolescents; age- and gender-specific BMI cut-off values of the $95^{\text {th }}$ percentile or 30 (whichever was smaller) or age- and gender-specific BMI cut-off values of the $85^{\text {th }}$ percentile but $<95^{\text {th }}$ percentile or equal to 30 (whichever was smaller) were suggested. In this study, girls had a significantly higher $\%$ body fat and a significantly higher WC $(p=0.001)$. Similar mean body fat values between age groups were observed in American [37] and Brazilian [38] girls, which showed an increase in the amount of body fat from the $25^{\text {th }}$ percentile to the $75^{\text {th }}$ percentile. Naturally, because of the action of sexual hormones, a progressive increase in body fat was observed in girls with maturation; however, their lower involvement in physical activities [39] and inadequate eating habits [40] may contribute to the increased body fat percentage levels as well. According to Mihalopoulos et al. [37], this 
Table 2 Percentile values summary statistics among Colombian-Indian Schoolchildren: Anthropometric outcomes

\begin{tabular}{|c|c|c|c|c|c|c|c|c|c|c|c|c|c|c|c|c|c|c|c|c|c|}
\hline Age (Doys) & $N$ & ean & SD & $P_{3}$ & 10 & $P_{25}$ & $P_{50}$ & $P_{75}$ & $P_{90}$ & $P_{97}$ & Ige (girls) & N & Miedn & SD & $P_{3}$ & $P_{10}$ & $P_{25}$ & $P_{50}$ & $P_{75}$ & $P_{90}$ & $P_{97}$ \\
\hline \multicolumn{22}{|l|}{ BMI $\left(\mathrm{kg} / \mathrm{m}^{2}\right)$} \\
\hline o 10 & r & & 3.4 & 5.9 & 9 & 6.8 & 8.6 & 22.8 & 8 & 26.1 & to 10.9 & 24 & 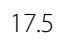 & 1.9 & 15.3 & 15.3 & 16.1 & 6.6 & 18.8 & 0.6 & 20.6 \\
\hline 1.9 & 31 & 0 & 1.5 & 5.1 & 8 & 17.6 & 18.6 & 19.9 & 6 & 20.8 & .9 & 23 & 18.6 & 1.5 & 16.2 & 16.6 & 17.7 & 18.5 & 19.3 & 21.4 & 21.5 \\
\hline to 120 & 58 & 9 & 1.7 & 4.6 & 3 & 7.0 & 8 & 18.9 & 9 & 22.1 & to 12.9 & 31 & 18.8 & 1.8 & 15.9 & 17.0 & 17.6 & 18.5 & 19.5 & 21.0 & 24.8 \\
\hline S.J & 32 & & & 17.1 & & 9 & & 22.1 & & 2 & 9 & 9 & & 1.7 & 15.8 & 5 & 18.0 & .5 & .7 & 3 & 3.8 \\
\hline O 14.9 & 38 & & 2 & 7.6 & 18.8 & 9.7 & 21.1 & 22.7 & .5 & 26.4 & to 14.9 & 33 & 19.7 & 2.0 & 15.9 & 16.9 & 18.9 & 19.7 & 20.2 & 21.9 & 26.0 \\
\hline 15 to 150 & 49 & & 2.2 & 3 & 19.7 & 21.0 & 22.8 & 50 & 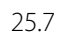 & 2 & 9 & 2 & 20.2 & 1.4 & 17.2 & 6 & 19.2 & 2 & .4 & .7 & 22.7 \\
\hline & 32 & & 2. & 3.4 & & 1.9 & & 25.6 & & 27.3 & & 33 & & 2.6 & 18.3 & 18.7 & 19.4 & 20.8 & 22.8 & 24.0 & 31.2 \\
\hline 17 to 17.9 & 5 & 24.0 & 2.7 & 6 & 20.5 & 21.7 & 23.5 & 25.7 & 4 & 30.0 & 9 & 42 & 2 & 1.9 & 18.1 & 18.7 & 20.1 & 21.4 & 23.1 & 8 & 25.8 \\
\hline \multicolumn{22}{|l|}{$W C(\mathrm{~cm})$} \\
\hline 9 & 27 & & 4.7 & 7.0 & 58.0 & 60.0 & 62.3 & 69.3 & 70.7 & 71.0 & 0.9 & 24 & 66.8 & 7.6 & 59.3 & 59.4 & 60.0 & 64.5 & 76.3 & 77.1 & 77.3 \\
\hline (3) & 31 & 64.8 & 6.8 & .4 & 58.0 & 61.0 & 63.8 & 66 & 5 & 87.5 & 9 & 23 & 6 & 5.0 & 4.0 & 5.4 & 60.2 & 4.0 & 66.5 & .2 & 77.3 \\
\hline 12 to 12.9 & 58 & 9 & 4. & 53.0 & 95 & 63.3 & 65.3 & 67.0 & 69.7 & 71.3 & 2.9 & 31 & 62 & 5.2 & 54.0 & 54.3 & 57.3 & 64.0 & 67.0 & 69.0 & 69.3 \\
\hline & 3 & & 6.0 & 5.7 & 60.9 & T.L & 2 & 72 & .4 & 83.7 & 9 & 39 & 7 & 6.0 & 8.1 & 63.0 & 66.0 & 70.3 & 3.0 & 78.0 & 83.9 \\
\hline to 14.9 & 38 & .9 & 4.4 & 62.1 & 64.0 & 66.1 & 70.0 & 72.5 & 76.5 & 79.2 & 14 to 14.9 & 33 & 69 & 6.1 & 61.0 & 63.7 & 64.5 & 67.0 & 75.3 & 79.1 & 82.0 \\
\hline 15 to 15.9 & $46 \mathrm{C}>\mathrm{s}$ & & 5.7 & 0 & 67.0 & 69.3 & 72.1 & 75.9 & 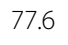 & 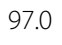 & 9 & 2 & 74.8 & 6.3 & 3 & 3 & 2.0 & 3 & .2 & 8 & 88.3 \\
\hline & 32 & & 4 & 3.8 & 3.6 & 71.0 & 74.2 & 77.0 & 80.7 & 85.1 & 9 & 33 & 77 & 5.9 & 66.0 & 67.8 & 73.0 & 77.0 & 82.8 & 84.9 & 87.0 \\
\hline 17 to 17.9 & 5 & 63.7 & 4.7 & 70 & 58.0 & (2) & 62.3 & 23 & 70.7 & 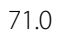 & 9 & 2 & 76.4 & 6.8 & 6 & 6 & 70.9 & 76.5 & 82.5 & 0 & 864 \\
\hline \multicolumn{22}{|l|}{$\mathrm{SS}(\mathrm{mm})$} \\
\hline 10 to 10.9 & 27 & & 2 & 4.0 & 4.0 & 5.0 & 6. & 8.0 & 1 & 10.0 & & 24 & 13 & 7.5 & 3.0 & 4 & 7.0 & 10.0 & 19.0 & 24.2 & 30.0 \\
\hline & 31 & & 2.6 & 4.3 & 5.5 & 6.5 & 8.0 & & & & & 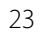 & & 3 & 6.0 & & & ) & 13.0 & 16.9 & 21.0 \\
\hline & 58 & & 3.8 & 5.0 & 5.3 & 6.2 & 7.2 & 9.0 & 11.0 & 23.6 & & 31 & 9.8 & 3.0 & 7.0 & 7.0 & 7.3 & 9.3 & 12.0 & 14.8 & 17.0 \\
\hline 13 to 13.9 & 32 & 8.0 & 2.2 & 5.0 & 5.1 & 6.5 & 7.7 & th & 11.0 & 15.0 & 9 & 39 & 1 & 5.5 & 3.1 & 7.0 & 12.0 & 15.0 & 20.0 & 3 & 252 \\
\hline $14.32-3$ & 38 & 8.7 & 3.1 & 5.0 & 6.0 & 7.0 & 8.0 & 9.3 & 11.0 & 20.2 & 14.9 & 33 & 16. & 5.3 & 8.0 & 9.4 & 12.2 & 15.0 & 20.0 & 25.2 & 27.0 \\
\hline 15 to 15.9 & 49 & 9.7 & 3.1 & 60 & 7 & 80 & 90 & 105 & 14.0 & 19.2 & 9 & 32 & 19 & 5.3 & 4.0 & 12.6 & 17.3 & 18.3 & 21.2 & 27.4 & 29.0 \\
\hline 16 to 16.9 & 32 & 9.8 & 2.8 & 7.0 & 7.0 & 7.3 & 9.0 & 12.0 & 13.7 & 10 & 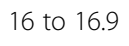 & 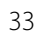 & & 5 & 10.0 & 11.6 & $r$ & 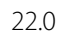 & .5 & 27.6 & 20.0 \\
\hline 170 & 52 & 6 & 2.7 & 70 & 7.0 & 9.0 & 10.2 & 12.0 & 14.7 & 16.8 & .9 & 42 & 21. & 5.0 & 7.1 & 14.5 & 18.0 & 22.3 & 25.0 & 26.7 & 29.0 \\
\hline \multicolumn{22}{|l|}{ TS (mm) } \\
\hline & 27 & 8.3 & 1. & 0.0 & 0.0 & 7.0 & 0.3 & 9.0 & 12.0 & 12.0 & & 24 & 10 & 3.9 & 4.0 & 4. & 1.0 & .3 & 12.0 & 16.6 & 17.0 \\
\hline & 31 & 9.9 & 2.9 & 60 & 6.7 & 8.0 & 9.0 & 120 & 14 & 15.3 & 9 & 23 & 10 & 3.0 & 70 & 7.1 & 83 & 10.0 & 13.0 & 15.3 & 180 \\
\hline 2.9 & 58 & 9.1 & 2.9 & 4.0 & 6.9 & 1.2 & 9.0 & 10.0 & 12.0 & 20.0 & 2.9 & 31 & y. & 1.5 & 7.0 & 1 & 8. & 9.3 & 11.0 & 11.9 & 12.0 \\
\hline 13 & 32 & 7.5 & 2.1 & 4.3 & 5.0 & 6.0 & 7.0 & 8.8 & 10.2 & 15.0 & 13 & 39 & 12.3 & 2.5 & 8.0 & 9.0 & 10.3 & 12.0 & 13.3 & 16.0 & 18.2 \\
\hline 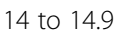 & 38 & I & 2.7 & 50 & $P_{0}+2$ & 70 & 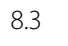 & 10.0 & 12 & 17.2 & 14 to 14.9 & 33 & 120 & 2.2 & م & 10.0 & 11.0 & 13.0 & 14.7 & 15.6 & 16 \\
\hline 15 & 49 & 8.3 & 1.9 & 5.0 & 6.0 & 7.0 & 8.0 & 9.0 & 10.3 & 12.7 & 9 & 32 & $142+2$ & 3.7 & 5.0 & 10.1 & 12.0 & 14.0 & 15.0 & 19.8 & 24.0 \\
\hline 16 to 16.9 & 32 & 0.1 & 0.4 & 5.0 & 3.0 & 6.0 & 1.0 & 10.0 & 11.0 & 23.0 & 16 to 16.9 & 33 & 14.6 & 2.3 & 11.0 & 11.4 & 13.0 & 14.0 & 16.0 & 18.0 & 0.0 \\
\hline 17 to 17.9 & 52 & 7.5 & 1.8 & 4.6 & 5.3 & 6.0 & 7.0 & 9.0 & 10.0 & 10.8 & 17 to 17.9 & 42 & 14.7 & 3.5 & 5.5 & 11.0 & 13.3 & 14.3 & 16.3 & 19.0 & 23.2 \\
\hline
\end{tabular}

$M$ mean, $S D$ standard deviation, $P$ percentile, $B M I$ body mass index, WC waist circumference

increase in body fat could be related to physical and sexual development, which is in line with results obtained in other research.

\section{Physical fitness}

In 2009, Ruiz et al. [41] systematically reviewed whether fitness in childhood was a predictor of cardiovascular disease risk factors, events and syndromes, quality of life and low back pain later in life. The present values may be useful in identifying adolescents at a higher risk for developing unfavorable health outcomes owing to their low fitness level. Recently, Ruiz, et al. [42] showed that the $5^{\text {th }}$ percentile to the $25^{\text {th }}$ percentile of levels of physical fitness was identified as the "pathological fitness level" or as a "warning sign"; thus, youth in or below the $25^{\text {th }}$ percentile should be examined to determine whether they have a 
Table 3 Percentile values summary statistics among Colombian-Indian Schoolchildren: Physical Fitness outcomes

\begin{tabular}{|c|c|c|c|c|c|c|c|c|c|c|c|c|c|c|c|c|c|c|c|c|c|}
\hline Age (boys) & N & Mean & SD & $P_{3}$ & $P_{10}$ & $P_{25}$ & $P_{50}$ & $P_{75}$ & $P_{90}$ & $P_{97}$ & Age (girls) & $N$ & Mean & SD & $P_{3}$ & $P_{10}$ & $P_{25}$ & $P_{50}$ & $P_{75}$ & $P_{90}$ & $P_{97}$ \\
\hline \multicolumn{22}{|c|}{$\overline{C R F}\left(\mathrm{~m} \mid \cdot \mathrm{kg} \cdot \mathrm{min}^{-1}\right)$} \\
\hline 10 to 10.9 & 27 & 52.4 & 2.7 & 48.4 & 48.4 & 50.4 & 52.8 & 55.3 & 55.9 & 55.9 & 10 to 10.9 & 24 & 48.6 & 4.8 & 43.2 & 43.3 & 45.6 & 48.0 & 51.4 & 57.5 & 60.8 \\
\hline 11 to 11.9 & 31 & 50.2 & 3.4 & 43.9 & 45.2 & 46.9 & 51.6 & 53.9 & 54.0 & 54.1 & 11 to 11.9 & 23 & 49.1 & 4.5 & 41.3 & 43.1 & 44.5 & 49.1 & 53.9 & 54.4 & 56.3 \\
\hline 12 to 12.9 & 58 & 50.7 & 3.3 & 43.1 & 46.0 & 48.0 & 51.2 & 53.0 & 53.5 & 58.0 & 12 to 12.9 & 31 & 46.3 & 5.3 & 35.4 & 39.8 & 41.2 & 47.4 & 51.0 & 53.0 & 53.7 \\
\hline 13 to 13.9 & 32 & 51.2 & 3.8 & 37.8 & 45.2 & 51.2 & 51.9 & 53.4 & 54.5 & 57.3 & 13 to 13.9 & 39 & 45.1 & 3.8 & 36.4 & 40.8 & 41.8 & 45.9 & 46.7 & 51.4 & 51.8 \\
\hline 14 to 14.9 & 38 & 50.7 & 4.3 & 40.1 & 44.9 & 47.5 & 51.6 & 53.2 & 55.9 & 58.6 & 14 to 14.9 & 33 & 43.0 & 4.3 & 31.9 & 37.5 & 39.5 & 42.9 & 45.5 & 49.4 & 50.5 \\
\hline 15 to 15.9 & 49 & 51.7 & 5.0 & 37.9 & 45.5 & 49.0 & 52.2 & 54.7 & 57.4 & 60.0 & 15 to 15.9 & 32 & 40.2 & 4.8 & 31.4 & 32.6 & 37.2 & 40.5 & 43.4 & 46.5 & 49.2 \\
\hline 16 to 16.9 & 32 & 51.3 & 4.8 & 39.3 & 44.9 & 47.4 & 52.6 & 55.7 & 56.2 & 58.3 & 16 to 16.9 & 33 & 41.4 & 4.8 & 27.6 & 34.3 & 38.4 & 42.1 & 45.0 & 46.4 & 50.0 \\
\hline 17 to 17.9 & 52 & 52.8 & 5.5 & 40.2 & 45.5 & 49.1 & 52.2 & 57.6 & 59.6 & 62.1 & 17 to 17.9 & 42 & 38.5 & 5.7 & 29.4 & 32.7 & 34.0 & 37.2 & 42.8 & 45.9 & 54.7 \\
\hline \multicolumn{22}{|c|}{ Standing broad jump (cm) } \\
\hline 10 to 10.9 & 27 & 131.3 & 11.4 & 119.0 & 119.0 & 120.3 & 132.0 & 146.0 & 146.3 & 146.3 & 10 to 10.9 & 24 & 111.9 & 13.1 & 88.3 & 91.2 & 104.0 & 110.2 & 126.0 & 130.2 & 130.4 \\
\hline 11 to 11.9 & 31 & 136.5 & 14.3 & 110.4 & 118.2 & 127.1 & 134.8 & 149.2 & 157.6 & 165.0 & 11 to 11.9 & 23 & 124.0 & 17.7 & 92.0 & 105.5 & 110.6 & 116.3 & 138.0 & 151.7 & 160.3 \\
\hline 12 to 12.9 & 58 & 143.2 & 19.3 & 108.4 & 122.0 & 129.8 & 142.3 & 151.3 & 165.7 & 198.7 & 12 to 12.9 & 31 & 131.6 & 20.6 & 91.6 & 108.3 & 117.2 & 128.8 & 150.0 & 166.0 & 166.3 \\
\hline 13 to 13.9 & 32 & 161.4 & 19.7 & 128.8 & 130.2 & 144.3 & 165.0 & 175.2 & 188.5 & 191.3 & 13 to 13.9 & 39 & 131.2 & 19.5 & 102.1 & 106.6 & 114.7 & 126.3 & 146.2 & 157.0 & 171.9 \\
\hline 14 to 14.9 & 38 & 165.9 & 19.8 & 128.1 & 144.4 & 150.2 & 162.7 & 181.1 & 194.1 & 201.4 & 14 to 14.9 & 33 & 136.7 & 16.6 & 114.0 & 119.4 & 122.4 & 134.0 & 152.2 & 158.8 & 171.9 \\
\hline 15 to 15.9 & 49 & 180.0 & 18.6 & 136.0 & 152.3 & 168.0 & 183.0 & 195.5 & 202.3 & 211.0 & 15 to 15.9 & 32 & 121.7 & 15.1 & 80.0 & 99.4 & 113.7 & 119.7 & 133.2 & 139.0 & 150.0 \\
\hline 16 to 16.9 & 32 & 186.4 & 19.3 & 137.0 & 156.5 & 176.3 & 189.0 & 200.0 & 204.4 & 223.0 & 16 to 16.9 & 33 & 131.0 & 15.2 & 106.0 & 108.4 & 121.0 & 133.0 & 139.5 & 151.8 & 165.8 \\
\hline 17 to 17.9 & 52 & 194.8 & 17.7 & 157.0 & 170.0 & 180.5 & 198.0 & 207.5 & 216.4 & 224.0 & 17 to 17.9 & 42 & 130.7 & 17.0 & 97.2 & 106.7 & 118.0 & 132.0 & 142.6 & 157.3 & 163.7 \\
\hline \multicolumn{22}{|c|}{ Handgrip (kg) } \\
\hline 10 to 10.9 & 27 & 13.5 & 0.8 & 12.2 & 12.2 & 12.5 & 13.9 & 13.9 & 13.9 & 13.9 & 10 to 10.9 & 24 & 13.5 & 2.6 & 6.4 & 8.8 & 12.7 & 13.9 & 14.2 & 17.3 & 17.5 \\
\hline 11 to 11.9 & 31 & 14.6 & 2.6 & 9.7 & 11.4 & 13.4 & 13.9 & 16.9 & 18.9 & 20.4 & 11 to 11.9 & 23 & 13.9 & 2.1 & 10.9 & 11.1 & 12.0 & 13.9 & 14.5 & 17.6 & 18.7 \\
\hline 12 to 12.9 & 58 & 15.9 & 3.8 & 10.9 & 11.5 & 13.6 & 14.7 & 17.6 & 20.7 & 26.1 & 12 to 12.9 & 31 & 13.7 & 2.6 & 7.5 & 9.5 & 12.7 & 13.9 & 15.2 & 16.5 & 19.1 \\
\hline 13 to 13.9 & 32 & 18.0 & 4.3 & 10.9 & 12.7 & 15.1 & 17.2 & 20.6 & 25.4 & 27.7 & 13 to 13.9 & 39 & 16.6 & 5.0 & 10.3 & 11.1 & 13.0 & 15.3 & 19.8 & 24.7 & 28.4 \\
\hline 14 to 14.9 & 38 & 19.2 & 4.0 & 10.8 & 13.6 & 16.4 & 19.3 & 22.5 & 23.8 & 26.7 & 14 to 14.9 & 33 & 17.7 & 4.0 & 9.5 & 12.0 & 15.4 & 17.7 & 20.4 & 22.8 & 25.4 \\
\hline 15 to 15.9 & 49 & 24.0 & 4.8 & 14.5 & 17.8 & 20.5 & 23.5 & 27.6 & 30.6 & 34.7 & 15 to 15.9 & 32 & 19.8 & 5.4 & 5.6 & 13.2 & 16.3 & 19.9 & 24.0 & 26.9 & 30.1 \\
\hline 16 to 16.9 & 32 & 28.6 & 6.7 & 14.0 & 19.2 & 24.3 & 27.4 & 34.1 & 36.1 & 46.4 & 16 to 16.9 & 33 & 17.5 & 4.8 & 10.1 & 12.0 & 13.7 & 17.0 & 20.7 & 23.9 & 32.2 \\
\hline 17 to 17.9 & 52 & 32.7 & 4.9 & 21.3 & 25.7 & 29.0 & 32.9 & 36.4 & 38.5 & 42.7 & 17 to 17.9 & 42 & 19.4 & 5.3 & 8.2 & 11.7 & 16.3 & 19.3 & 22.5 & 26.8 & 30.1 \\
\hline \multicolumn{22}{|c|}{$4 \times 10 \mathrm{~m}$ run $(\mathrm{s})$} \\
\hline 10 to 10.9 & 27 & 12.6 & 1.6 & 15.2 & 15.2 & 14.2 & 12.3 & 11.2 & 10.9 & 10.9 & 10 to 10.9 & 24 & 13.6 & 1.1 & 16.4 & 15.7 & 14.2 & 13.3 & 12.8 & 12.5 & 12.3 \\
\hline 11 to 11.9 & 31 & 12.2 & 0.7 & 14.5 & 13.1 & 12.7 & 12.1 & 11.7 & 11.4 & 11.2 & 11 to 11.9 & 23 & 13.2 & 0.8 & 15.0 & 14.6 & 13.7 & 13.2 & 12.5 & 12.3 & 12.0 \\
\hline 12 to 12.9 & 58 & 11.8 & 0.7 & 13.4 & 12.6 & 12.3 & 11.7 & 11.3 & 10.8 & 10.7 & 12 to 12.9 & 31 & 12.6 & 0.7 & 15.0 & 13.2 & 12.9 & 12.6 & 12.3 & 11.6 & 11.3 \\
\hline
\end{tabular}


Table 3 Percentile values summary statistics among Colombian-Indian Schoolchildren: Physical Fitness outcomes (Continued)

\begin{tabular}{|c|c|c|c|c|c|c|c|c|c|c|c|c|c|c|c|c|c|c|c|c|c|}
\hline 13 to 13.9 & 32 & 11.6 & 0.7 & 13.1 & 12.8 & 12.0 & 11.5 & 10.9 & 10.7 & 10.5 & 13 to 13.9 & 39 & 12.3 & 0.7 & 14.0 & 13.0 & 12.8 & 12.5 & 11.7 & 11.4 & 11.2 \\
\hline 14 to 14.9 & 38 & 11.5 & 0.6 & 12.9 & 12.5 & 11.8 & 11.5 & 10.8 & 10.7 & 10.5 & 14 to 14.9 & 33 & 12.3 & 1.1 & 14.9 & 14.2 & 12.9 & 12.2 & 11.6 & 10.9 & 10.2 \\
\hline 15 to 15.9 & 49 & 11.2 & 0.8 & 13.3 & 12.3 & 11.5 & 11.0 & 10.6 & 10.4 & 10.0 & 15 to 15.9 & 32 & 12.9 & 0.8 & 14.8 & 13.8 & 13.5 & 13.0 & 12.4 & 11.7 & 11.4 \\
\hline 16 to 16.9 & 32 & 10.8 & 0.7 & 13.0 & 12.0 & 11.4 & 10.5 & 10.4 & 10.2 & 9.8 & 16 to 16.9 & 33 & 12.8 & 1.4 & 16.9 & 14.2 & 13.3 & 12.7 & 11.7 & 11.1 & 10.7 \\
\hline 17 to 17.9 & 52 & 10.7 & 0.7 & 12.9 & 11.5 & 10.9 & 10.6 & 10.2 & 10.1 & 9.4 & 17 to 17.9 & 42 & 12.6 & 1.1 & 16.1 & 13.8 & 13.2 & 12.6 & 11.8 & 11.3 & 10.9 \\
\hline
\end{tabular}

$M$ mean, $S D$ standard deviation, $P$ percentile, $C R F$ cardiorespiratory fitness 


\section{Morphological component}
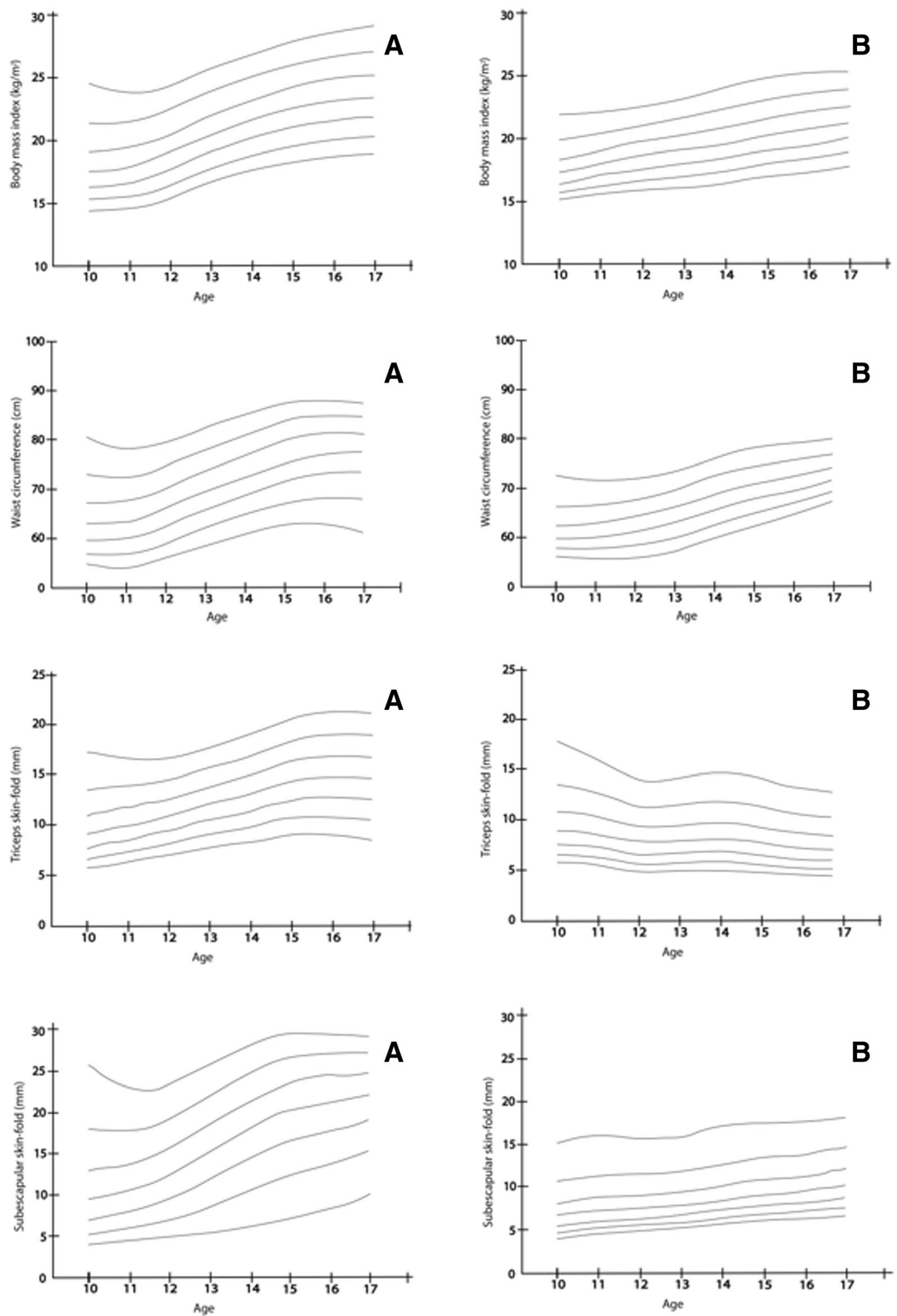

Fig. 1 Smoothed (LMS method) centile curves (from the bottom to the top: $P_{31}, P_{10}, P_{25}, P_{50}, P_{75}, P_{90}, P_{97}$ ) among Nasa Indigenous: morphological component. $\mathbf{a}$ boys and $\mathbf{b}$ girls 10-17.9 years of age 


\section{Musculoskeletal component}
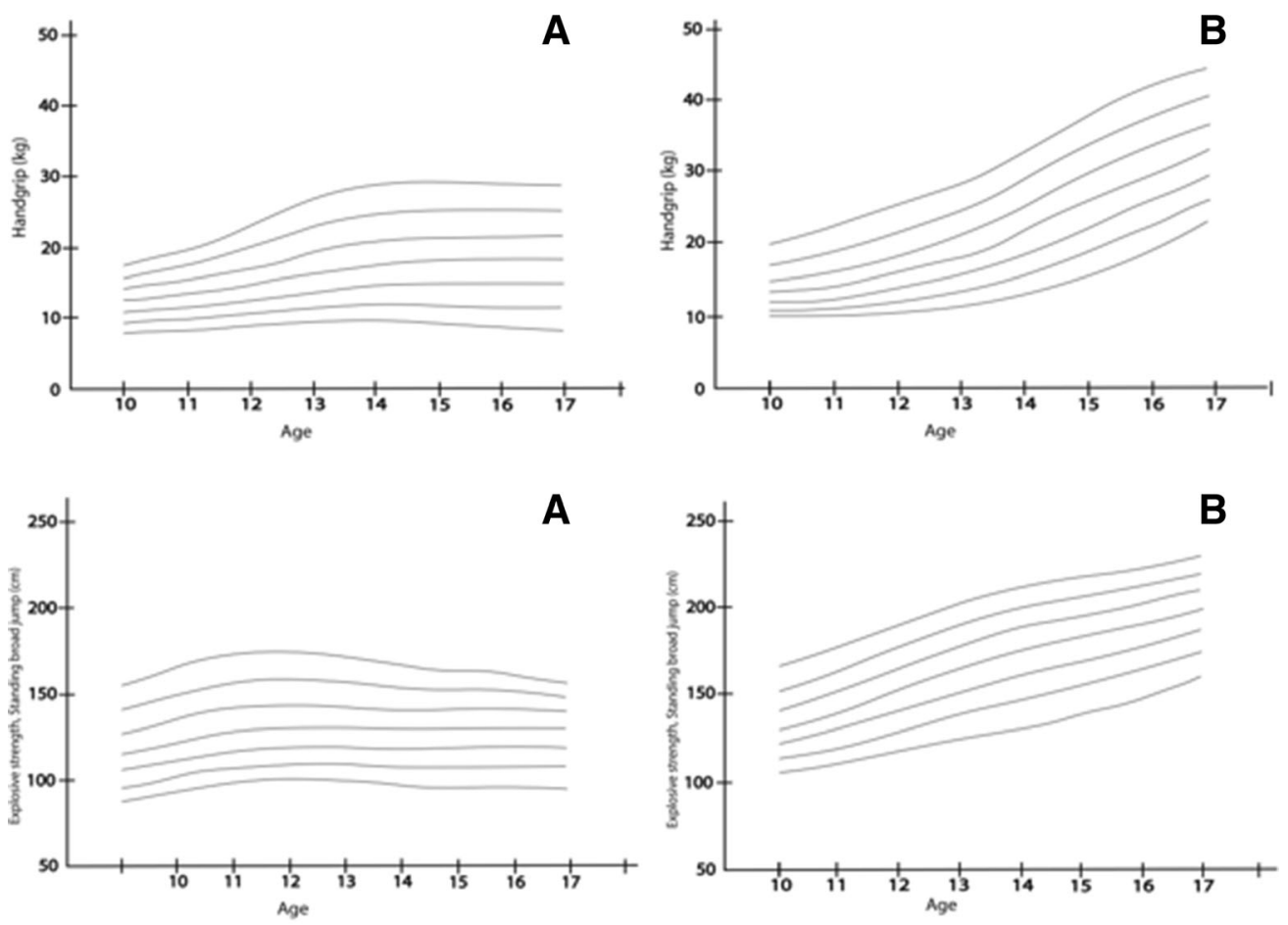

Motor component
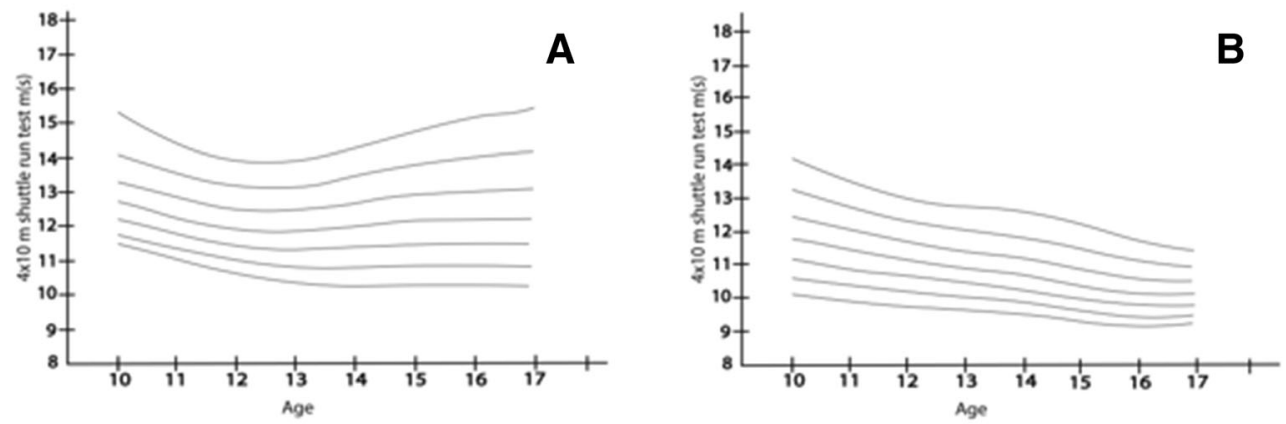

Cardiorespiratory component
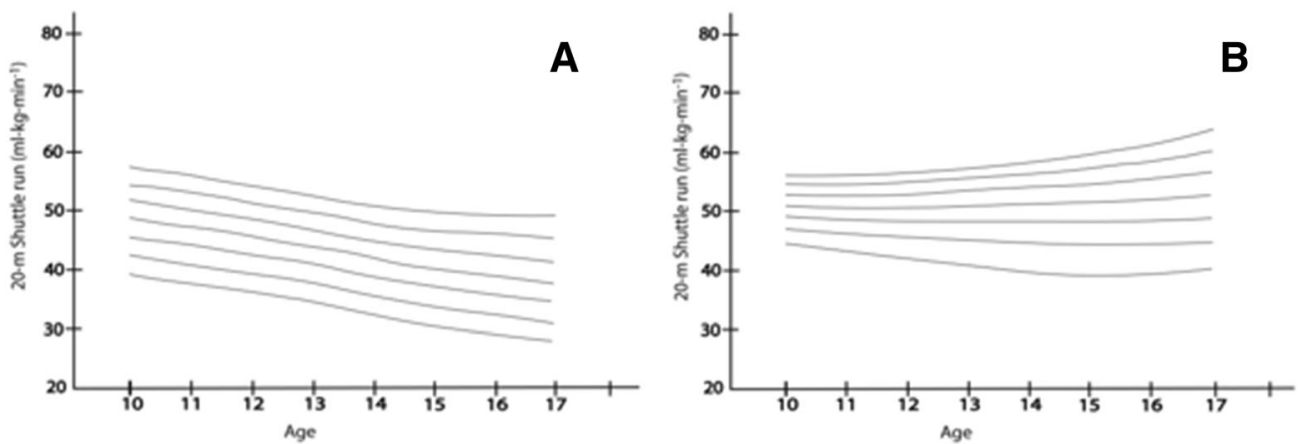

Fig. 2 Smoothed (LMS method) centile curves (from the bottom to the top: $P_{31}, P_{10}, P_{25}, P_{50}, P_{75}, P_{90}, P_{97}$ ) among Nasa Indigenous: Physical fitness component. $\mathbf{a}$ boys and $\mathbf{b}$ girls $10-17.9$ years of age 
Table 4 Reference values ( $50^{\text {th }}$ percentile or mean) for physical fitness from cited studies

\begin{tabular}{|c|c|c|c|c|c|c|c|c|c|}
\hline Age (boys) & $\begin{array}{l}\text { Present study } \\
n=576\end{array}$ & $\begin{array}{l}\text { Colombia }[72,76] \\
n=7268\end{array}$ & $\begin{array}{l}\text { UK }[77,78] \\
n=7147\end{array}$ & $\begin{array}{l}\mathrm{EU}[46]^{a} \\
n=3428\end{array}$ & Age (girls) & $\begin{array}{l}\text { Present study } \\
n=576\end{array}$ & $\begin{array}{l}\text { Colombia }[72,76] \\
n=7268\end{array}$ & $\begin{array}{l}\text { UK }[77,78] \\
n=7147\end{array}$ & $\begin{array}{l}\text { EU }[46]^{a} \\
n=3428\end{array}$ \\
\hline \multicolumn{10}{|c|}{$\overline{C R F\left(m l \cdot k g \cdot m^{-1}\right)^{c}}$} \\
\hline 10 to 10.9 & 52.8 & 22.0 & $47.1^{\mathrm{b}}$ & $51.6^{\mathrm{b}}$ & 10 to 10.9 & 48.0 & 16.0 & $44.7^{\mathrm{b}}$ & $46.8^{\mathrm{b}}$ \\
\hline 11 to 11.9 & 51.6 & 23.5 & $45.9^{b}$ & $51.1^{\mathrm{b}}$ & 11 to 11.9 & 49.1 & 18.0 & $43.0^{\mathrm{b}}$ & $47.5^{\mathrm{b}}$ \\
\hline 12 to 12.9 & 51.2 & 27.0 & $45.3^{b}$ & $51.9^{b}$ & 12 to 12.9 & 47.4 & 20.0 & $41.9^{b}$ & $46.6^{\mathrm{b}}$ \\
\hline 13 to 13.9 & 51.9 & 34.0 & $45.2^{\mathrm{b}}$ & $50.0^{\mathrm{b}}$ & 13 to 13.9 & 45.9 & 21.0 & $40.7^{b}$ & $44.4^{\mathrm{b}}$ \\
\hline 14 to 14.9 & 51.6 & 40.0 & $46.6^{\mathrm{b}}$ & $50.1^{\mathrm{b}}$ & 14 to 14.9 & 42.9 & 23.0 & $39.2^{b}$ & $41.6^{\mathrm{b}}$ \\
\hline 15 to 15.9 & 52.2 & 48.0 & $45.7^{\mathrm{b}}$ & $50.2^{\mathrm{b}}$ & 15 to 15.9 & 40.5 & 22.0 & $37.2^{b}$ & $41.1^{\mathrm{b}}$ \\
\hline 16 to 16.9 & 52.6 & 52.0 & $46.4^{b}$ & $49.9^{b}$ & 16 to 16.9 & 42.1 & 25.0 & $37.8^{\mathrm{b}}$ & $39.5^{\mathrm{b}}$ \\
\hline 17 to 17.9 & 52.2 & 54.0 & - & $49.6^{\mathrm{b}}$ & 17 to 17.9 & 37.2 & 25.0 & - & $38.6^{\mathrm{b}}$ \\
\hline \multicolumn{10}{|c|}{ Standing broad jump (cm) } \\
\hline 10 to 10.9 & 132.0 & 118.0 & 138.0 & - & 10 to 10.9 & 110.2 & 102.0 & 126.0 & - \\
\hline 11 to 11.9 & 134.8 & 123.0 & 143.0 & - & 11 to 11.9 & 116.3 & 107.0 & 133.0 & - \\
\hline 12 to 12.9 & 142.3 & 126.0 & 149.0 & - & 12 to 12.9 & 128.8 & 110.0 & 140.0 & - \\
\hline 13 to 13.9 & 165.0 & 139.0 & 156.0 & 159.0 & 13 to 13.9 & 126.3 & 114.0 & 145.0 & 140.0 \\
\hline 14 to 14.9 & 162.7 & 148.0 & 166.0 & 176.0 & 14 to 14.9 & 134.0 & 115.0 & 150.0 & 144.0 \\
\hline 15 to 15.9 & 183.0 & 158.0 & 178.0 & 189.0 & 15 to 15.9 & 119.7 & 115.0 & 154.0 & 145.0 \\
\hline 16 to 16.9 & 189.0 & 163.0 & 189.0 & 199.0 & 16 to 16.9 & 133.0 & 117.0 & 156.0 & 147.0 \\
\hline 17 to 17.9 & 198.0 & 165.0 & - & 208.0 & 17 to 17.9 & 132.0 & 120.0 & - & 150.0 \\
\hline \multicolumn{10}{|c|}{ Handgrip (kg) } \\
\hline 10 to 10.9 & 13.9 & 14.1 & 16.6 & - & 10 to 10.9 & 13.9 & 13.4 & 15.5 & - \\
\hline 11 to 11.9 & 13.9 & 15.6 & 19.6 & - & 11 to 11.9 & 13.9 & 15.3 & 18.7 & - \\
\hline 12 to 12.9 & 14.7 & 17.5 & 22.6 & - & 12 to 12.9 & 13.9 & 18.1 & 21.2 & - \\
\hline 13 to 13.9 & 17.2 & 21.1 & 27.2 & 26.2 & 13 to 13.9 & 15.3 & 19.5 & 23.5 & 23.6 \\
\hline 14 to 14.9 & 19.3 & 23.8 & 32.5 & 32.2 & 14 to 14.9 & 17.7 & 21.9 & 25.8 & 25.2 \\
\hline 15 to 15.9 & 23.5 & 28.5 & 39.0 & 37.7 & 15 to 15.9 & 19.9 & 21.5 & 26.9 & 26.2 \\
\hline 16 to 16.9 & 27.4 & 31.1 & - & 41.8 & 16 to 16.9 & 17.0 & 22.7 & - & 26.6 \\
\hline 17 to 17.9 & 32.9 & 33.5 & - & 45.1 & 17 to 17.9 & 19.3 & 23.3 & - & 27.6 \\
\hline \multicolumn{10}{|c|}{$4 \times 10 \mathrm{~m}$ run $(\mathrm{s})$} \\
\hline 10 to 10.9 & 12.3 & 13.8 & - & - & 10 to 10.9 & 13.3 & 15.0 & - & - \\
\hline 11 to 11.9 & 12.1 & 13.8 & - & - & 11 to 11.9 & 13.2 & 14.5 & - & - \\
\hline 12 to 12.9 & 11.7 & 13.4 & - & - & 12 to 12.9 & 12.6 & 14.4 & - & - \\
\hline 13 to 13.9 & 11.5 & 13.1 & - & 12.0 & 13 to 13.9 & 12.5 & 14.5 & - & 12.8 \\
\hline 14 to 14.9 & 11.5 & 12.9 & - & 11.7 & 14 to 14.9 & 12.2 & 14.3 & - & 12.7 \\
\hline 15 to 15.9 & 11.0 & 12.5 & - & 11.2 & 15 to 15.9 & 13.0 & 14.3 & - & 12.7 \\
\hline 16 to 16.9 & 10.5 & 12.3 & - & 10.9 & 16 to 16.9 & 12.7 & 14.5 & - & 12.6 \\
\hline 17 to 17.9 & 10.6 & 11.9 & - & 10.9 & 17 to 17.9 & 12.6 & 14.3 & - & 12.6 \\
\hline
\end{tabular}

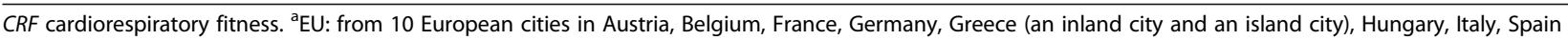
and Sweden

${ }^{\mathrm{b}}$ mean. ${ }^{\mathrm{C}} \mathrm{O}_{2 \text { peak }}\left(\mathrm{ml} \cdot \mathrm{kg}^{-1} \cdot \mathrm{min}^{-1}\right)$ predicted using the Leger et al. equation [25]. - Not reported

cardiovascular risk factor. Reports have shown that low levels of self-reported physical activity or low cardiorespiratory fitness are associated with insulin resistance in other indigenous groups [43, 44]. However, few studies available in the literature have investigated physical fitness profiles with similar socio-cultural characteristics and from the same ethnic origin [45].

Previously in adolescent populations, Ortega et al. [46] first published European fitness reference values for 12.5-17.5-year-old youths from 10 cities (HELENA 
study) and reported sex- and age-specific physical fitness levels. Our results were not comparable to those from Ortega et al. [46] for adolescents aged 10-17.9 years. For example, the $\mathrm{P}_{50}$ of the standing long jump was $172.0 \mathrm{~cm}$ vs $120.5 \mathrm{~cm}$ for Colombian Nasa Indian and European boys, respectively, and $127.0 \mathrm{~cm}$ vs $110.7 \mathrm{~cm}$ for Nasa Indian and European girls, respectively. The $\mathrm{P}_{50}$ of handgrip was an average of $21.5 \mathrm{~kg}$ vs $11.8 \mathrm{~kg}$ for Nasa Indian and European boys, respectively, and $16.2 \mathrm{~kg}$ vs $10.8 \mathrm{~kg}$ for Nasa Indian and European girls, respectively. In addition, the $\mathrm{P}_{50}$ of the $20-\mathrm{m}$ shuttle run (stage) was 8.0 vs 2.0 for Nasa Indian and European boys, respectively, and 6.0 vs 2.0 for Nasa Indian and European girls, respectively. Likewise, Tremblay et al. [47] reported normative data for aerobic fitness and muscular strength for Canadian 11-19-year-old youths; however, only the $50^{\text {th }}$ percentile was reported. For example, in the study of Tremblay et al. [47], the performance in the 20-m shuttle run $\left(\mathrm{VO}_{2} \mathrm{max}\right.$ in $\left.\mathrm{ml} \cdot \mathrm{kg} \cdot \mathrm{min}^{-1}\right)$ at the $50^{\text {th }}$ percentile of $11-14$-year-olds was $54.9 \mathrm{ml} \cdot \mathrm{kg} \cdot \mathrm{min}^{-1}$ and $48.9 \mathrm{ml} \cdot \mathrm{kg} \cdot \mathrm{min}^{-1}$ in boys and girls, respectively. In the present study, the performance in $\mathrm{VO}_{2} \mathrm{max}$ at the $50^{\text {th }}$ percentile of 11-17.9-year-olds was $51.9 \mathrm{ml} \bullet \mathrm{kg} \cdot \mathrm{min}^{-1}$ and $43.3 \mathrm{ml} \cdot \mathrm{kg} \cdot \mathrm{min}^{-1}$ for boys and girls, respectively. In addition, in the study of Tremblay et al. [47], the performance in handgrip strength at the $50^{\text {th }}$ percentile was $25 \mathrm{~kg}$ and $22 \mathrm{~kg}$ in boys and girls, respectively, which was calculated as the sum of the best right- and left-hand attempts. In our study, performance in the handgrip test at the $50^{\text {th }}$ percentile of $10-17.9$-yearolds was $21.5 \mathrm{~kg}$ and $16.2 \mathrm{~kg}$ for boys and girls, respectively. In terms of speed/agility, the values for boys were similar to those of three studies (Spanish [48], European [46] and Norwegian [49]), whereas the girls' performance was lower than that of the three analyzed studies.

Previous research indicates that such low fitness levels can linger on into adulthood in which low cardiorespiratory fitness or low muscular strength is associated with increased mortality risk $[50,51]$. However, differences in the environment alone do not appear to tell the entire story, particularly in elucidating why certain populations and ethnic groups experience a disproportionately high prevalence of cardiovascular disease when they adopt a Western lifestyle. The classic example of this is the Pima Indians, who when living a traditional rural lifestyle in Mexico are lean, active and have a low diabetes prevalence, but when living in the US, are generally obese and have prevalence of diabetes mellitus and other noncommunicable diseases in the adult population of $\sim 40 \%$ [52]. This pattern is also evident in other indigenous populations throughout the Americas and Australasia [53].

Compared to Nasa Indian adolescents in another studies, our sample had a significantly better performance in the musculoskeletal (SBJ), cardiorespiratory and motor components. Therefore, explaining the differences between urban and rural adolescents remains speculative and studies on the topic from other countries are inconsistent. One possible explanation for the differences in physical fitness profiles among indigenous adolescents may be the differences in moderate to vigorous physical activity [54] or differences in body fat distribution [55]. Probably, children living in rural areas may have more opportunities for active play or active transportation, as well as a reduced access to technologies such as the internet, which contributes to those children meeting the recommendations for physical activity [56]. Also, urban youth have more barriers that can restrict the freedom of children living in these areas, including spaces for playing and practicing physical activities. Additionally, in the rural areas, the youth normally helped their parents in work activities, reducing the time available for sedentary leisure activities. Specifically, the community of Cauca is characterised by smallholders and family agriculture, which in theory allows for the greater inclusion of youth in the daily work activities of their parents.

Physical activity and fitness have been found to be independently associated with certain cardiovascular risk factors among children and adolescents [57]. Contrarily, in Latin-American, urban Ecuadorian adolescents had better physical fitness and blood lipid profiles than rural adolescents, independent of time spent sedentary [58]. In summary, the observed high prevalence and sex differences of unhealthy cardiorespiratory fitness, particularly in girls, may be explained by the behavioral and environmental risk factors to which the Nasa community is currently exposed, including diet, lifestyle, and smoking. The lower levels of physical fitness and the excess weight in girls may stem from excess caloric consumption, lower caloric expenditure (due to reduced physical activity), or both, which may produce a vicious cycle. However, other environmental and socioeconomic correlates must be explored.

\section{Limitations and strengths}

There are a few limitations of this study. Firstly, the cross-sectional nature we cannot discern the direction of the observed associations between physical fitness and future cardiovascular risk, which may indeed be reciprocal. Adolescents with healthy body composition and healthy physical fitness may be more likely to engage in physical activity, which may lead to healthier cardiorespiratory and muscular fitness and contributes to the prevention of obesity $[52,53]$. Furthermore, the maintenance of muscle mass, as indicated by healthy muscle fitness, can contribute to higher resting metabolic rate and consequently have a preventive effect on fat mass accumulation [58]. Secondly, we did not measure important variables associated with blood lipids such as 
levels of physical activity, sex hormone levels, and familial health background. Third, the estimation of $\mathrm{VO}_{2} \mathrm{max}$ from the FITNESSGRAM standards of the $20 \mathrm{~m}$-shuttle run is known to vary with the equation used. A previous study [59] has tested the degree of agreement between various equations used to estimate $\mathrm{VO}_{2} \max$ and the actual the $\mathrm{VO}_{2} \max$. We were unable to confirm, for example, that the observed associations remain after control for physical activity or pubertal stage as others have shown due to lack of such data in this study. However, such limitations do not compromise the results obtained when validating these results. Finally, the small number of studies on the indigenous population did not allow us to make comparisons with the results of this work. The majority of the published fitness reference values are for children from high income countries in North America [60-62], Asia/Oceania and Europe, [63-68], whereas there is a scarcity of reference values for children using harmonized measures of fitness in Latin-America [69] and other low- and middle-income countries (LMICs) undergoing a nutrition transition, [70] making impossible to evaluate secular trends within these regions. Colombia is in the midst of a nutrition transition that is mirroring the changes occurring elsewhere in the world, such as an increase in the overweight/obese population and a general decrease in its chronically undernourished population [68]. Furthermore, despite their larger burden of chronic disease and the alarming increase in the prevalence of obesity in children in Colombia, [69] for example, LMICs are also substantially underrepresented in physical activity intervention research [71, 72]. Previously, in indigenous populations, we have reported that children living in rural areas and in geographic regions with lower economic and structural development generally have lower serum concentrations of micronutrients than in children from urban areas [73-76]. Likewise, in the dietary study we conducted in Villamor [77], only $13.4 \%$ of the protein in the diets of children was derived from eggs and milk, with $40 \%$ of protein coming from meat. Colombia is a country that is geographically, climatically and ethnically diverse. Clearly, these differences could affect food supply, dietary practices, and consequently micronutrient intakes. Indigenous and other ethnic groups of Colombia are very diverse, which leads to different dietary patterns and climates. Colombia's rapid economic development and modernization has led to the "westernization" of the Colombian diet, characterized by an increase in the absolute number of calories, saturated fat, and fast food consumed, and a decrease in the consumption of legumes, fruit, and cereals [77]. These dietary patterns may partially explain our results, given the effect of diet on physical fitness in adolescents.

On the other hand, our decision to categorize physical fitness according to health predictive value instead of using continuous variables can be considered a strength of the study as it allowed for greater public health interpretability. Another potential strength of the study was the use of four health-related, valid, and reliable field tests recommended for Latin-American youth fitness assessment [78]. Finally, we provided an accurate description of the physical fitness and anthropometric characteristics of the Colombian indigenous youths and their age-related variations.

\section{Conclusion}

In summary, indigenous boys showed better than girls in cardiorespiratory fitness, lower- and upper-limb strength and speed/agility and girls performed better in low back flexibility. These values may be useful in identifying adolescents being at higher risk for developing unfavourable health outcomes owing to their low fitness level $\left(<10^{\text {th }}\right.$ percentile). Also, these cut-offs are especially interesting in educational setting due to school could play a major role in helping to identify adolescents with low physical fitness. Simultaneously, this study allows for more accurate categorization, which considers a youth age and gender, and enables comparisons among normative values from other countries. In addition, they are important because monitoring health-related physical fitness early in life might contribute to substantial improvements in life expectancy and reduced risk of chronic diseases such as obesity, cardiometabolic disease, skeletal and mental health in the indigenous population.

\section{Abbreviations \\ ALPHA: Assessing Levels of Physical Activity; BMl: Body mass index; CRF: Cardio-respiratory fitness; EUROFIT: European Physical Fitness Test Battery; HELENA: Healthy Lifestyle in Europe by Nutrition in Adolescence Study; ICC: Intraclass correlation coefficient; LMICs: Low- and middle-income countries; LMS: L curve (Box-Cox power to remove skewness), M curve (median), S curve (coefficient of variation); SD: Standard deviation}

\section{Acknowledgements}

The authors are grateful to the Nasa community for the data used in this study.

\section{Funding}

The "Fuprecol Study" was carried out with the financial support of Instituto Colombiano para el Desarrollo de la Ciencia y la Tecnología "Francisco José de Caldas" COLCIENCIAS (Contract N 671-2014 Code 122265743978).

\section{Availability of data and materials}

The study data have legal restrictions and ethical imposed by the authors' IRB (Manuela Beltrán (Resolution UMB N 02-1902-2014). The explanation of these restrictions is because they are children and adolescent students of Public Schools Colombia (Law N 1.581, Octuber 2012 and National Decret Nº 1377 de 2013). Avalaible: http://www.alcaldiabogota.gov.co/sisjur/normas/Norma1.jsp?i=49981 and http://www.oei.es/quipu/colombia/codigo_infancia.pdf

Contact for the raw data: Study Details of data acces/requests Universidad del Rosario. The initial contact point for collaborations is Professor Robinson Ramirez-Velez (robinson.ramirez@urosario.edu.co)

References (for data access arrangements): Centro de Estudios en

Medición de la Actividad Física (CEMA), Universidad del Rosario [computer file]. Bogota, Colombia: FUPRECOL Data Archive [distributor], May 2015. "FUPRECOL study" (ASOCIACIÓN DE LA FUERZA PRENSIL CON MANIFESTACIONES TEMPRANAS DE RIESGO CARDIOVASCULAR EN NIÑOS Y ADOLESCENTES COLOMBIANOS. "ESTUDIO FUPRECOL" for Spanish). 


\section{Authors' contributions}

JAR-S and RR-V participated in the study design, acquisition of the data, data analysis and interpretation and drafting the manuscript. NG-H, MI and JEC-B participated in the data analysis and interpretation and drafting the manuscript. All authors have read and approved the manuscript

\section{Competing interests}

The authors declare that they have no competing interests.

\section{Consent for publication}

Not applicable.

\section{Ethics approval and consent to participate}

Informed consent was obtained through written informed consent with a parent or guardian of the participant. In addition, child assent was obtained verbally. The Ethics Committee of the Manuela Beltrán (Resolution UMB Nº2-1902-2014), which is recognized by the Colombian National Ethics Committee, provided ethical approval. Information that could lead to identifying participants was available only to staff who had legitimate access.

\section{Author details}

${ }^{1}$ Grupo de Investigación en Pedagogía, Licenciatura en Ciencias del Deporte y la Educación Física, Institución Universitaria Antonio Jose Camacho, Cali, Colombia. ${ }^{2}$ Vicerrectoria de Investigaciones, Maestría en Ciencias y Tecnologías del Deporte y la Actividad Física, Universidad Manuela Beltrán, Bogotá, D.C, Colombia. ${ }^{3}$ Centro de Estudios en Medición de la Actividad Física (CEMA), Escuela de Medicina y Ciencias de la Salud, Universidad de Rosario, Bogotá, D.C, Colombia. ${ }^{4}$ Department of Health Sciences, Public University of Navarra, Pamplona, Spain. ${ }^{5}$ Laboratorio de Ciencias de la Actividad Física, el Deporte y la Salud, Universidad de Santiago de Chile, USACH, Santiago, Chile. ${ }^{6}$ Universidad San Sebastián, Santiago, Chile.

\section{Received: 28 April 2016 Accepted: 8 September 2016}

\section{Published online: 13 September 2016}

\section{References}

1. Ortega FB, Ruiz JR, Castillo MJ, Sjostrom M. Physical fitness in childhood and adolescence: a powerful marker of health. Int J Obes (Lond). 2008;32(1):1-11.

2. Kelishadi R, Gheiratmand R, Ardalan G, Adeli K, Mehdi Gouya M, CASPIAN Study Group. Association of anthropometric indices with cardiovascular disease risk factors among children and adolescents: CASPIAN Study. Int J Cardiol. 2007;117(3):340-8.

3. Ekelund U, Anderssen SA, Froberg K, Sardinha LB, Andersen LB, Brage S. Independent associations of physical activity and cardiorespiratory fitness with metabolic risk factors in children: the European youth heart study. Diabetologia. 2007;50:1832-40.

4. Ortega FB, Labayen I, Ruiz JR, Kurvinen E, Loit HM, Harro J, et al. Improvements in fitness reduce the risk of becoming overweight across puberty. Med Sci Sports Exerc. 2011;43:1891-7.

5. Eisenmann JC. Aerobic fitness, fatness and the metabolic syndrome in children and adolescents. Acta Paediatr. 2007;96(12):1723-9.

6. Hurtig-Wennlof A, Ruiz JR, Harro M, Sjostrom M. Cardiorespiratory fitness relates more strongly than physical activity to cardiovascular disease risk factors in healthy children and adolescents: the European Youth Heart Study. Eur J Cardiovasc Prev Rehabil. 2007:14(4):575-81.

7. Grøntved A, Ried-Larsen M, Møller NC, Kristensen PL, Froberg K, Brage S, Andersen LB. Muscle strength in youth and cardiovascular risk in young adulthood (the European Youth Heart Study). Br J Sports Med. 2015;49(2):90-4.

8. Ross J, Hamlin M. Maori physical activity: a review of an indigenous population's participation. Health Promot J Austr. 2007;18(1):73-6.

9. Ramírez-Vélez R, Rodrigues-Bezerra D, Correa-Bautista JE, Izquierdo M, Lobelo F. Reliability of health-related physical fitness tests among Colombian children and adolescents: the FUPRECOL Study. PLoS One. 2015; 10(10):e0140875

10. Cooper Institute for Aerobics Research. The prudential Fitnessgram: test administration manual. Champaign: Human Kinetics; 2004.

11. The President's Council on Physical Fitness and Sports. The President's Challenge: The Health Fitness Test. Available at: http://www.presidentschallenge.org/ educators/program_details/health_fitness_test.aspx. Accessed 4 Oct 2012.

12. Council of Europe Committee for the Development of Sport. EUROFIT: handbook for the EUROFIT tests of physical fitness. Strasbourg: Council of Europe; 1993.
13. Canadian Society for Exercise Physiology (CSEP). The Canadian Physical Activity, Fitness \& Lifestyle Approach (CPAFLA): CSEPHealth \& Fitness Program's healthrelated appraisal and counselling strategy. Ottawa: CSEP; 2003.

14. Australian Council for Health Physical Education and Recreation (ACHPER). Handbook for the Australian fitness education award manual. South Australia: ACHPER Publications; 1996.

15. Ruiz JR, Castro-Piñero J, España-Romero V, Artero EG, Ortega FB, Cuenca MM, et al. Field-based fitness assessment in young people: the ALPHA health-related fitness test battery for children and adolescents. Br J Sports Med. 2011;45:518-24.

16. Williams DR. Race and health: basic questions, emerging directions. Ann Epidemiol. 1997;7:322-33.

17. Caprio S, Daniels SR, Drewnowski A, Kaufman FR, Palinkas LA, Rosenbloom AL, et al. Influence of race, ethnicity, and culture on childhood obesity: implications for preventionand treatment. Obesity (Silver Spring). 2008;16(12):2566-77.

18. Caprio S, Daniels SR, Drewnowski A, Kaufman FR, Palinkas LA, Rosenbloom AL et al. Influence of race, ethnicity, and culture on childhood obesity: implications for prevention and treatment: a consensus statement of Shaping America's Health and the Obesity Society. Diabetes Care. 2008;31(11):2211-21.

19. Garcia S, Sarmiento OL, Forde I, Velasco T. Socio-economic inequalities in malnutrition among children and adolescents in Colombia: the role of individual, household- and community-level characteristics. Public Health Nutr. 2012:13:1-16.

20. Lopez AD, Mathers CD, Ezzati M, Jamison DT, Murray CJ, editors. Global burden of disease and risk factors. Washington, DC: World Bank; 2006.

21. Departamento Administrativo Nacional de Estadística (DANE). Los grupos étnicos de Colombia en el censo de 2005. Análisis de Resultados, Bogotá, Colombia. 2007.

22. Cole TJ, Flegal KM, Nicholls D, Jackson AA. Body mass index cut offs to define thinness in children and adolescents: international survey. BMJ. 2007:335:194.

23. Slaughter MH, Lohman TG, Boileau RA, Horswill CA, Stillman RJ, Van Loan $M D$, et al. Skinfold equations for estimation of body fatness in children and youths. Hum Biol. 1988;60:709-23.

24. Taylor RW, Jones IE, Williams SM, Goulding A. Body fat percentages measured by dual-energy $\mathrm{X}$-ray absorptiometry corresponding to recently recommended body mass index cutoffs for overweight and obesity in children and adolescents aged 3-18 y. Am J Clin Nutr. 2002;76(6):1416-21.

25. Leger LA, Mercier D, Gadoury C, Lambert J. The multistage 20 metre shuttle run test for aerobic fitness. J Sports Sci. 1988;6:93-101.

26. Lobelo F, Pate RR, Dowda M, Liese AD, Ruiz JR. Validity of cardiorespiratory fitness criterion-referenced standards for adolescents. Med Sci Sports Exerc. 2009:41:1222-9.

27. Matsudo SMM, Matsudo VKR. Self-assessment and physician assessment of sexual-maturation in Brazilian boys and girls - concordance and reproducibility. Am J Hum Biol. 1994:6:451-5.

28. Artero EG, España-Romero V, Castro-Piñero J, Ortega FB, Suni J, CastilloGarzon MJ, Ruiz JR. Reliability of field-based fitness tests in youth. Int J Sports Med. 2011;32(3):159-69.

29. Cole TJ, Green PJ. Smoothing reference centile curves: the LMS method and penalized likelihood. Stat Med. 1992;11:1305-9.

30. Royston P. Wright EM. Goodness-of-fit statistics for age-specific reference intervals. Stat Med. 2000;19:2943-62.

31. Cole TJ, Freeman JV, Preece MA. British 1990 growth reference centiles for weight, height, body mass index and head circumference fitted by maximum penalized likelihood. Stat Med. 1998:17:407-9.

32. Minatto G, Sousa TF, Carvalho WR, Ribeiro RR, Santos KD, Petroski EL. Association between cardiorespiratory fitness and body fat in girls. Rev Paul Pediatr. 2016. doi: 10.1016/j.rpped.2016.02.006

33. Chinn S, Cole TJ, Preece MA. Growth charts for ethnic populations in UK (letter). Lancet. 1996:347:839-40.

34. Moreno LA, Mesana MI, González-Gross M, Gil CM, Fleta J, Wärnberg J, AVENA Study Group. Anthropometric body fat composition reference values in Spanish adolescents. The AVENA Study. Eur J Clin Nutr. 2006;60(2):191-6.

35. Cardona-ARIAS JA, Llanes-Agudelo OM. Hypertension and associated factors in Embera-Chami indigenous. CES Med. 2013;27:31-43.

36. Spear BA, Barlow SE, Ervin C, Ludwig DS, Saelens BE, Schetzina KE, Taveras EM. Recommendations for treatment of child and adolescent overweight and obesity. Pediatrics. 2007:120:S254-88.

37. Mihalopoulos NL, Holubkov R, Young P, Dai S, Labarthe DR. Expected changes in clinical measures of adiposity during puberty. J Adolesc Health. 2010:47:360-6.

38. Minatto G, Petroski EL, Silva DA. Body fat, muscular and cardiorespiratory fitness according to sexual maturation among Brazilian adolescents from a town of German colonization. Rev Paul Pediatr. 2013;31:189-97. 
39. Moliner-Urdiales D, Ruiz JR, Vicente-Rodriguez G, Ortega FB, Rey-Lopez JP, España-Romero $\mathrm{V}$, et al. Associations of muscular and cardiorespiratory fitness with total and central body fat in adolescents: the HELENA study. $\mathrm{Br}$ J Sports Med. 2011:45:101-8.

40. Tardido AP, Falcão MC. The impact of the modernization in the nutritional transition and obesity. Rev Bras Nutr Clin. 2006;21:117-24.

41. Ruiz JR, Castro-Pinero J, Artero EG, Ortega FB, Sjostrom M, Suni J, et al. Predictive validity of health-related fitness in youth: a systematic review. $\mathrm{Br} J$ Sports Med. 2009;43:909-23.

42. Ruiz JR, Huybrechts I, Cuenca-García M, Artero EG, Labayen I, Meirhaeghe A, on behalf of the HELENA study group. Cardiorespiratory fitness and ideal cardiovascular health in European adolescents. Heart. 2015;101:766-73.

43. Gill JM, Bhopal R, Douglas A, Wallia S, Bhopal R, et al. Sitting time and waist circumference are associated with glycemia in U.K. South Asians: data from 1,228 adults screened for the PODOSA trial. Diabetes Care. 2011;34:1214-8.

44. Celis-Morales CA, Perez-Bravo F, Ibañes L, Sanzana R, Hormazabal E, Ulloa N, et al. Insulin resistance in Chileans of European and indigenous descent: evidence for an ethnicity X environment interaction. PLoS One. 2011;6(9):e24690.

45. Ramírez-Vélez R, Anzola A, Martinez-Torres J, Vivas A, Tordecilla-Sanders A, Prieto-Benavides D, Izquierdo M, Correa-Bautista JE, Garcia-Hermoso A. Metabolic Syndrome and Associated Factors in a Population-Based Sample of Schoolchildren in Colombia: The FUPRECOL Study. Metab Syndr Relat Disord. 2016. doi: 10.1089/met.2016.0058. [Epub ahead of print].

46. Ortega FB, Artero EG, Ruiz JR, Espana-Romero V, Jimenez-Pavon D, VicenteRodriguez $\mathrm{G}$, et al. Physical fitness levels among European adolescents: the HELENA study. Br J Sports Med. 2011;45:20-9.

47. Tremblay MS, Shields M, Laviolette M, Craig CL, Janssen I, Connor Gorber S. Fitness of Canadian children and youth: results from the 2007-2009 Canadian Health Measures Survey. Health Rep. 2010;21:7-20.

48. Ortega FB, Ruiz JR, Castillo MJ, Moreno LA, González-Gross M, Wärnberg J, et al. Low level of physical fitness in Spanish adolescents. Relevance for future cardiovascular health (AVENA study). Rev Esp Cardiol. 2005;58(8):898-909.

49. Haugen $T$, Hoigaard R, Seiler S. Normative data of BMl and physical fitness in a Norwegian sample of early adolescents. Scand J Public Health. 2014;42:67-73.

50. Suriano K, Curran J, Byrne SM, Jones TW, Davis EA. Fatness, fitness, and increased cardiovascular risk in young children. J Pediatr. 2010;157:552-8.

51. Blair SN, Kohl 3rd HW, Paffenbarger Jr RS, Clark DG, Cooper KH, Gibbons LW. Physical fitness and all-cause mortality. A prospective study of healthy men and women. JAMA. 1989;262:2395-401.

52. Schulz LO, Bennett PH, Ravussin E, Kidd JR, Kidd KK, Esparza J, et al. Effects of traditional and western environments on prevalence of type 2 diabetes in Pima Indians in Mexico and the U.S. Diabetes Care. 2006;29:1866-71.

53. Yu CH, Zinman B. Type 2 diabetes and impaired glucose tolerance in aboriginal populations: a global perspective. Diabetes Res Clin Pract. 2007;78:159-70.

54. Ekelund U, Luan J, Sherar LB, Esliger DW, Griew P, Cooper A. Moderate to vigorous physical activity and sedentary time and cardiometabolic risk factors in children and adolescents. JAMA. 2012;307:704-12.

55. Browning LM, Hsieh SD, Ashwell M. A systematic review of waist-to-height ratio as a screening tool for the prediction of cardiovascular disease and diabetes: 0.5 could be a suitable global boundary value. Nutr Res Rev. 2010; 23:247-69.

56. Andrade Neto F, Eto FN, Pereira TS, Carletti L, Molina MC. Active and sedentary behaviours in children aged 7 to 10 years old: the urban and rural contexts, Brazil. BMC Public Health. 2014;14:1174.

57. Andrade S, Ochoa-Avilés A, Lachat C, Escobar P, Verstraeten R, Van Camp J, et al. Physical fitness among urban and rural Ecuadorian adolescents and its association with blood lipids: a crosssectional study. BMC Pediatr. 2014;14:106.

58. Ramírez-Vélez R, Meneses-Echavez JF, González-Ruíz K, Correa JE. Muscular fitness and cardiometabolic risk factors among Colombian young adults. Nutr Hosp. 2014;30(4):769-75

59. Boiarskaia EA, Boscolo MS, Zhu W, Mahar MT. Cross-validation of an equating method linking aerobic FITNESSGRAM(R) field tests. Am J Prev Med. 2011;41:S124-30.

60. Pate RR, Wang CY, Dowda M, Farrell SW, O'Neill JR. Cardiorespiratory fitness levels among US youth 12 to 19 years of age: findings from the 1999-2002 National Health and Nutrition Examination Survey. Arch Pediatr Adolesc Med. 2006;160:1005-12.

61. Carrel AL, Bowser J, White D, Moberg DP, Weaver B, Hisgen J, et al. Standardized childhood fitness percentiles derived from school-based testing. J Pediatr. 2012;161:120-4.
62. De Miguel-Etayo P, Gracia-Marco L, Ortega FB, Intemann T, Foraita R, Lissner $L$, IDEFICS consortium. Physical fitness reference standards in European children: the IDEFICS study. Int J Obes (Lond). 2014;38:S57-66.

63. Roriz De Oliveira MS, Seabra A, Freitas D, Eisenmann JC, Maia J. Physical fitness percentile charts for children aged 6-10 from Portugal. J Sports Med Phys Fitness. 2014;54(6):780-92.

64. Gulías-González R, Sánchez-López M, Olivas-Bravo Á, Solera-Martínez M, Martínez-Vizcaíno V. Physical fitness in Spanish schoolchildren aged 6-12 years: reference values of the battery EUROFIT and associated cardiovascular risk. J Sch Health. 2014;84(10):625-35.

65. Vanhelst J, Béghin L, Fardy PS, Ulmer Z, Czaplicki G. Reliability of healthrelated physical fitness tests in adolescents: the MOVE Program. Clin Physiol Funct Imaging. 2016;36(2):106-11.

66. Ramírez-Vélez R, Morales O, Peña-lbagon JC, Palacios-López A, PrietoBenavides DH, Vivas $\mathrm{A}$, et al. Normative reference values for handgrip strength in Colombian schoolchildren: the Fuprecol study. J Strength Cond Res. 2016. [Epub ahead of print]. doi: 10.1519/JSC.0000000000001459.

67. Cohen DD, Voss C, Taylor MJ, Stasinopoulos DM, Delextrat A, Sandercock GR. Handgrip strength in English schoolchildren. Acta Paediatr. 2010;99(7):1065-72.

68. Cohen DD, Voss C, Taylor MJ, Delextrat A, Ogunleye AA, Sandercock GR. Ten-year secular changes in muscular fitness in English children. Acta Paediatr. 2011:100(10):e175-7.

69. Aguilar de Plata AC, Pradilla A, Mosquera M, Gracia de Ramírez AB, Ortega JG, Ramírez-Vélez R. Centile values for anthropometric variables in Colombian adolescents. Endocrinol Nutr. 2011;58(1):16-23.

70. Muthuri SK, Wachira LJ, Onywera VO, Tremblay MS. Correlates of objectively measured overweight/obesity and physical activity in Kenyan school children: results from ISCOLE-Kenya. BMC Public Health. 2014;14:436.

71. Parra DC, lannotti L, Gomez LF, Pachón H, Haire-Joshu D, Sarmiento OL, Kuhlmann AS, Brownson RC. The nutrition transition in Colombia over a decade: novel household classification system of anthropometricmeasures. Arch Public Health. 2015;73(1):12.

72. Sarmiento OL, Parra DC, González SA, González-Casanova I, Forero AY, Garcia J. The dual burden of malnutrition in Colombia. Am J Clin Nutr. 2014; 100(6):1628S-35.

73. Heath GW, Parra DC, Sarmiento OL, Andersen LB, Owen N, Goenka S, Montes F, Brownson RC, Lancet Physical Activity Series Working Group. Evidence-based intervention in physical activity: lessons from around the world. Lancet. 2012;380(9838):272-81.

74. Martínez-Torres J, Meneses-Echavéz JF, Ramírez-Vélez R. Prevalence and demographic factors associated with vitamin A deficiency in Colombian children aged 12-59 months. Endocrinol Nutr. 2014;61(9):460-6.

75. Ramírez-Vélez R, Palacios-López A, Humberto Prieto-Benavides D, Enrique Correa-Bautista J, Izquierdo M, Alonso-Martínez A, et al. Normative reference values for the $20 \mathrm{~m}$ shuttle-run test in a population-based sample of school-aged youth in Bogota, Colombia: the FUPRECOL study. Am J Hum Biol. 2016. [Epub ahead of print]. doi: 10.1002/ajhb.22902.

76. Ramírez-Vélez R, Matínez-Torres J, Meneses-Echavez JF. Prevalence and demographic factors associated with ferritin deficiency in Colombian children, 2010. Rev Peru Med Exp Salud Publica. 2014;31(2):237-42.

77. Villamor E, Mora-Plazas M, Forero Y, Lopez-Arana S, Baylin A. Vitamin B-12 status is associated with socioeconomic level and adherence, to an animal food dietary pattern in Colombian school children. J Nutr. 2008;138:1391-8.

78. Rendo-Urteaga T, de Moraes AC, Collese TS, Manios Y, Hagströmer M, Sjöström M, HELENA study group. The combined effect of physical activity and sedentary behaviors on a clustered cardio-metabolic risk score: the Helena study. Int J Cardiol. 2015;186:186-95. 